\title{
Evaluation of Antimicrobial Activities and Bioactive Compounds of Different Extracts Related to Syrian Traditional Products of Damask Rose (Rosa damascena)
}

\author{
Nasser Thallaj', Mohamed Isam Hasan Agha², Abdul Hakim Nattouf3, Chadi Khatib², \\ Ahmad Karaali ${ }^{4}$, Aoula Moustapha ${ }^{5}$, Louay Labban ${ }^{1 *}$ \\ ${ }^{1}$ Faculty of Pharmacy, Al Jazeera Private University, Deir ez-Zor, Syria \\ ${ }^{2}$ Department of Pharmacognosy, Faculty of Pharmacy, Damascus University, Damascus, Syria \\ ${ }^{3}$ Department of Pharmaceutics and Pharmaceutical Technology, Faculty of Pharmacy, Damascus University, Damascus, Syria \\ ${ }^{4}$ Higher Institute of Marine Research, Tishreen University, Latakia, Syria \\ ${ }^{5}$ Department of Pharmacology and Toxicology, Faculty of Pharmacy, Al-Baath University, Homs, Syria \\ Email: *drlouay@gmail.com
}

How to cite this paper: Thallaj, N., Agha, M.I.H., Nattouf, A.H., Khatib, C., Karaali, A., Moustapha, A. and Labban, L. (2020) Evaluation of Antimicrobial Activities and Bioactive Compounds of Different Extracts Related to Syrian Traditional Products of Damask Rose (Rosa damascena). Open Access Library Journal, 7: e6302.

https://doi.org/10.4236/oalib.1106302

Received: April 5, 2020

Accepted: May 5, 2020

Published: May 8, 2020

Copyright $\odot 2020$ by author(s) and Open Access Library Inc.

This work is licensed under the Creative Commons Attribution International License (CC BY 4.0).

http://creativecommons.org/licenses/by/4.0/

\section{(c) (i) Open Access}

\begin{abstract}
Rosa damascena or Damask rose is an aromatic shrub-like plant which has been originated from Damascus region. This flower has been used in traditional medicine and traditional cuisine for centuries. Different extracts have been prepared from its flowers as essential oils, rose water or jams. Very recently, UNESCO has inscribed the element of the Damascus rose or Rosa damascena and associated heritage practices and craftsmanship on the UNESCO Intangible Cultural Heritage of Humanity list for its importance in making essential oils which can be used in traditional medicine. In this study, our team compared the effectiveness of different extracts of bioactive compounds related to traditional products and compared different products which are known to be effective in reducing bacterial loads. The results showed that the traditional Syrian traditional mixture of Damask rose jam with honey and Propolis was effective for most of the studied pathogens. It was followed by black seeds honey, which was effective against bacteria, followed by the second generation antibiotics. Thus, the Syrian traditional mixture of Damask rose jam with honey and Propolis can be considered as an antibacterial and as a functional food (healthy food) which is rich in vitamins (vitamin $\mathrm{C}$ and some vitamins $\mathrm{B}$ and $\mathrm{D}$ ), and minerals (iron, calcium) and other minerals. In addition, this product is rich in antioxidants, and this confirms what was stated in ancient Arabic manuscripts about the importance of this Syrian traditional mixture in treatment of many diseases.
\end{abstract}




\section{Subject Areas}

Medicinal Chemistry

\section{Keywords}

Rosa damascena, Damask Rose, Aromatherapy, Traditional Medicine, Functional Food, Essential Oil, Antimicrobial, Antioxidant, Pathogenic Bacteria

\section{Introduction}

Since ancient times, Syrians have practiced traditional medicine just as many eastern and western civilizations have, where common natural ingredients were used in traditional methods for healing ailments and diseases [1] [2]. The United Nations Educational, Scientific and Cultural Organization (UNESCO) has inscribed Damascus rose or Rosa damascena and associated heritage practices and craftsmanship on the UNESCO Intangible Cultural Heritage of Humanity list [3]. This was achieved by the efforts of the Syria Trust for Development. The practices and craftsmanship associated with the Damascus rose are mainly practiced by farmers and families in Al-Mrah village, in rural Damascus, which was inscribed in 2019 on the Representative List of the Intangible Cultural Heritage of Humanity.

The Syrian people possess the expertise and the knowledge of producing essential oils and traditional medicine from the Damascus rose, among other things, as well as the village community and families who organize the annual Damascene Rose Festival. The Damask rose begins to bloom in May when the handpicking commences and the annual festival kicks off. Farmers and their family members head to the fields in the early morning to handpick the roses and then return home by afternoon, when the whole family helps in sorting the rose buds that are dried to make drinks such as tea. The other rose petals are stored and prepared for distillation. The women of the village help each other in making rose syrup, jam and pastries as they sing along to local tunes. Apothecaries sell the dried Damascene rose for its numerous medicinal benefits. The festival attracts people from many surrounding villages who come to take part in the festivities and to enjoy the atmosphere. Rose-infused dishes are presented by women and a collection of folk songs and incantations celebrating the Rose are sung by all. The festival is a testament to the element's unfading cultural significance for its bearers and their enduring commitment to its safeguarding [3].

Historically, Rosa damascena mill was originally an eastern Mediterranean hybrid between $R$. gallica and $R$. Phoenicia [4], and is the member of Rosaceae family [5]. Commonly known as Damask rose [6]; this plant is cultivated in all over the world including Syria, Iran, Europe, Bulgaria, Turkey and India [7].

There are evidences that Damask rose is an ancient plants [8] [9] [10], it's first 
grew wildly, and it's still self-growing in Syri, Caucasus, Morocco and Andalusia [11], and often thought that the origin of Damask rose is the Middle East [12]. The French Crusader Robert de Brie, who took part in the Siege of Damascus in 1148 during the second crusade, is sometimes credited for bringing the Damask rose from Syria to Europe. The name of the rose refers to the city of Damascus in Syria, known also for its steel (Damask steel), fabrics (Damask) and roses [13]. Other accounts state that the ancient Romans brought it to their colonies in England, and a third account is that the physician of King Henry VIII gifted him one circa 1540 [14], so the Damask rose is a sustainable national wealth, and it is the rose that embraced history just as the name of Damascus embraced the oldest inhabited city in the world. The aromatic fragrance of the rose arrived across the science through the successive time periods and Damask rose still preserves its name and its fragrant fragrance.

More than one thousand years ago Avicenna (980-1037AD), described the various medical benefits of Damask rose such as its gastrointestinal and cardiac tonic effects [15], cosmetic properties in eliminating the unpleasant odor of sweat, repair of skin and mucosal lesions and he also mentioned its anti-nociceptive and anti-inflammatory properties [16] [17]; And the important ancient writer on aromatics is the Spanish cosmetologist Abu al-Qasim al-Zahrawi (Albucasis) (936-1013AD). He dealt with aromatic and cosmetics in the nineteenth book of his great work, Kitab "al-Tasrif", this text would likely have added much to this work [9], he used The term of Mä 'itriah: “ماء عطرية" (pl. miāh 'itriah “ "عطرية related to aromatherapy which is an aromatic herbal water deepened on rose water, which is prepared by distillation [18].

Albucasis presents the recipes of nine types of distilled plants as a following: "jawzeen" (jowri) water (rose water which caliphs used as a scent in the past), camphor water, musk water, saffron water, clove water, sandalwood water, apple water, date water, after shave aromatic water; most of it is prepared base on the rose water and sometimes on the drink water for using it as a solvent for extraction the essence of the plant [18] (Figure 1).

Later, The medicinal benefits of Rosa damascena was reported by an ancient Syrian physician Ibn al-Nafis (1213-1288AD), as a prescription for honey and rose as paste to treat stomach aches, liver problems, digestion disorders, and joints stiffness in addition to treating chest diseases [20].

Nowadays in aromatherapy, Damask rose essential oil has a soothing effect on the emotions and in particular, depression, apathy and grief. It is used for insomnia, headache, migraine, nervous tension and stress-related emotion [21].

$R$. damascena is a perennial bushy shrub reaching approximately 1 to 2 meters in height with large, showy and colorful flowers. The leaves are imparipinnate and compound with 5 - 7 leaflets [22] [23] (Figure 2). The flowers are usually solitary, more rarely in twos and threes, on 2 to $3 \mathrm{~cm}$ long, thickly-glandular pedicles. The calyx is round to pear-shaped and is usually thickly covered with stem glands and gland bristles. The velvety petals are pink to purple, 2 to $3 \mathrm{~cm}$ 


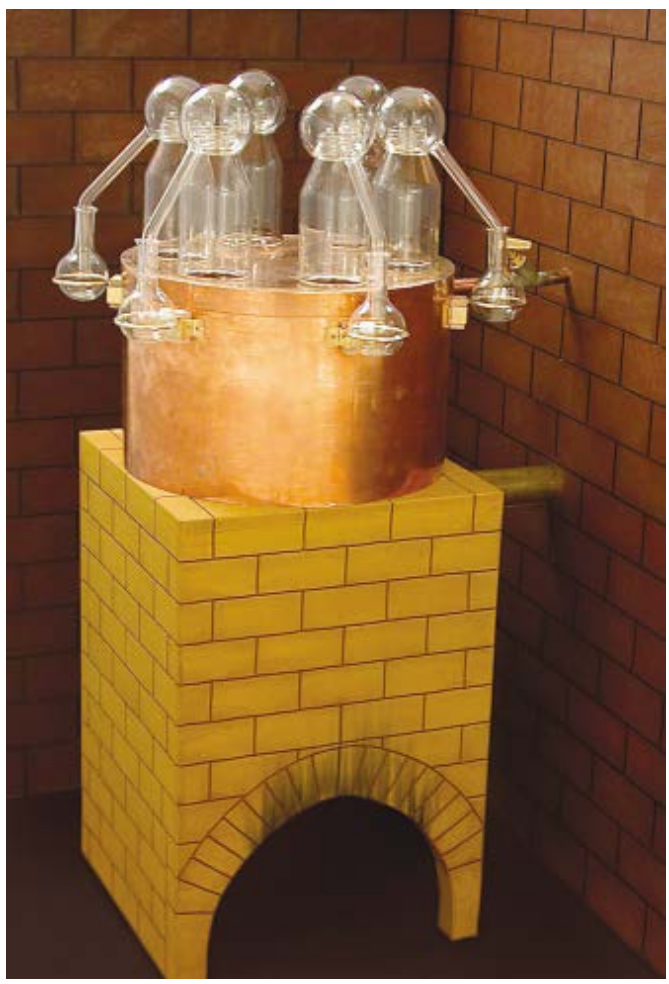

Figure 1. Apparatus for distilling rose water. Replica built by the Institute for the history of Arab-Islamic Sciences, According to a description by the physician az-Zahrâwî from the late tenth century in Muslim Spain. Image courtesy of Fuat Sezgin, Institute for the History of Arab-Islamic Sciences, University of Frankfurt, Germany [19].

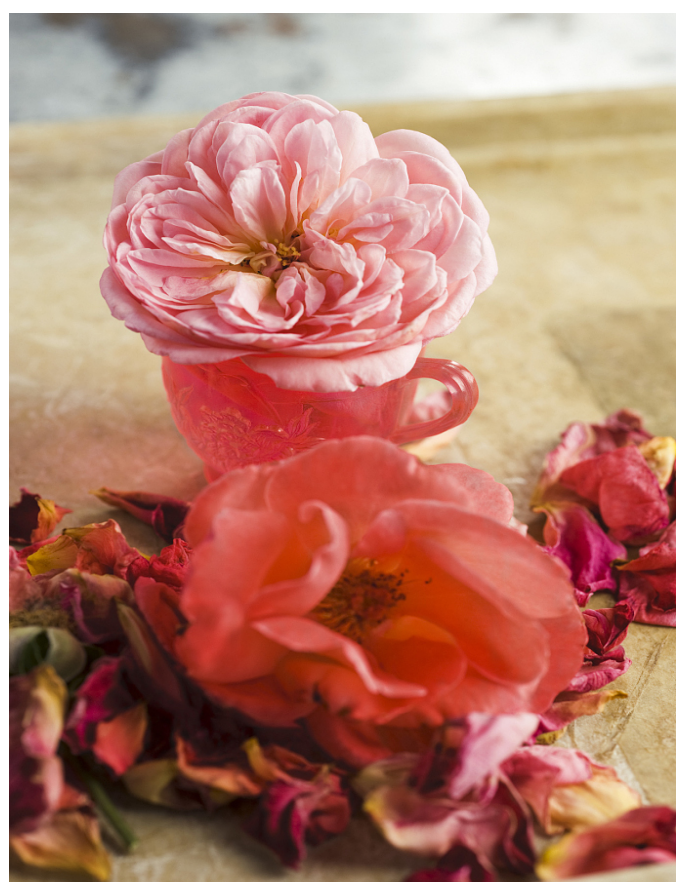

Figure 2. The damask rose/VCG photo [25]. 
long and wide [24] (Figure 3).

The Damask rose has taken on its importance and fame and has been spread around the world due to its many benefits (aromatic, cosmetic and great nutritional benefits) [26], However, $R$. damascena is mainly known for its perfuming effects [27], essential oil of this kind of rose is one of the most expensive ones in the world markets [28], In order to produce $1 \mathrm{~kg}$ of essential oil it needs 4 tons of flowers approximately.

The volatile oil of Rosa damascena (in the fresh blossoms) contains chief components such as-citronellol, geraniol, nerol, phenyl ethanol, Including as well-linalool, and citral [24].

In ancient Islamic Manuscript "al-Tașrîf liman 'ajiza 'an al-tà ālîp” Albucasis mentions the distillation of rose water method as a following [29] Pour five pounds of musk-rose water into a glass bottle and add an ounce of Indian aloeswood, preferably ground one. A bit more than an ounce is good as it enhances the scent. Seal the bottle and wrap it up with a clean, spotless cloth and leave it for five days. Then gently strain the mixture into a distillation bowl and pour it into another bottle. Take two pounds of the resulting water and add five pennyweights of saffron, five pennyweights of pure clove, and two pennyweights of nutmeg. Pour the mixture into a distillation bowl and seal it for one day then put it in a distillation oven on smokeless, gentle heat. Once you see water dripping, remove the bowl from heat. Separately, grind a carat of musk, a carat of ambergris, and two pennyweights of camphor. Pour them all to the distillation bowl and seal it again. Put it in the oven in order for the mixture to be distilled. This distillation process is characterized by three different colors representing three stages:

Stage one: Pour the white distilled water into the first bottle; it is for caliphs and princes.

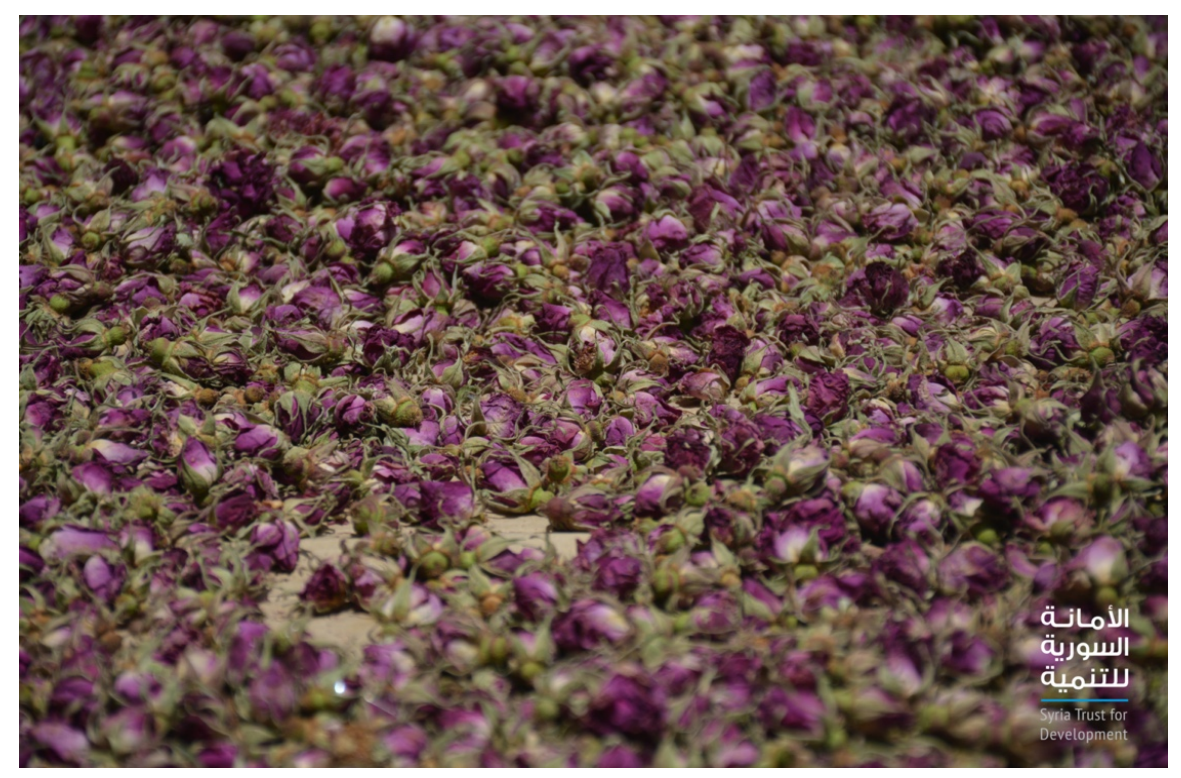

Figure 3. The damask rose @ courtesy of the Syria trust for Development, 2016. 
Stage two: Pour the slightly yellowish distilled water into the second bottle and seal it with wax. It is for those below caliphs and princes.

Stage three: Pour the reddish distilled water into the third bottle. It is for women [18].

Damask roses are used in cooking as a flavoring ingredient or spice. Rose water and powdered roses are used in Syria, Persian, Indian, and Middle Eastern cuisine. Rose water is often sprinkled on meat dishes, while rose powder is added to sauces. Whole flowers, or petals, are also used in the herbal tea "zuhurat Shameh" (Damask traditional tisane tea). The most popular use, however, is in the flavoring of desserts such as ice cream, jam, etc. [13], beside the traditional syrup called Jallab (Arabic: جلاب/jallāb) which is a type of Damask rose and fruit syrup popular in the Middle East made from carob, dates, grape molasses and rose water. Jallab is very popular in Syria, Jordan, Palestine and Lebanon. It is made mainly of grape molasses, grenadine syrup, and rose water, then smoked with Arabic incense. It is usually sold with crushed ice and floating pine nuts and raisins [30] (Figure 4).

Damask rose flowers are used in traditional medicine internally for diarrhea, tuberculosis of the lungs, pulmonary, catarrh and asthma, hemorrhage and leucorrhea. Externally, it is used for inflammations of the oral and pharyngeal mucosa, suppurating wounds and lid inflammation [24], also Damask rose water in used in Syria in many cosmetic industries, ointment, soap, shampoo, and in the pharmaceutical industry, such as a tranquilizer, gas expeller, tonic for the blood circulation, liver, and gallbladder problems; Besides its application in aromatic and food industries, some valuable characteristics of Damask rose oil such as anti-HIV, antibacterial and antioxidant activities have been established during last two decades [32].

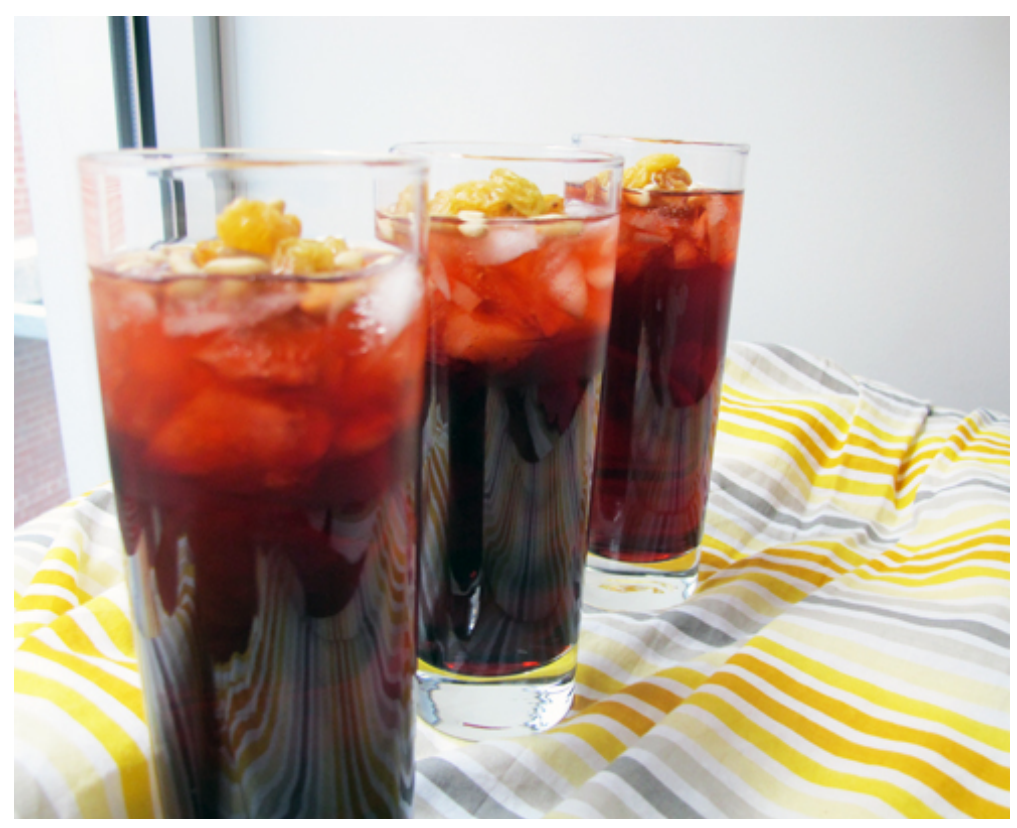

Figure 4. Jallab damask rose traditional syrup [31]. 
Damask rose flowers are available for use as whole, crude and powdered drug forms for internal and external use, as herbal tea add 1 to 2 gm of rose petals to 1 cup $(200 \mathrm{ml})$ water, and as rose vinegar add 60 gm petals to $750 \mathrm{ml}$ red wine vinegar, the daily dosage of Tea infusion is up to 3 cups per day. It is also used for rinses and washes; the daily dosage of powder is 5 to $10 \mathrm{gm}$ with honey or liquid. The leaves can be applied directly to the eyes [24].

The traditional recipe of Damask rose jam with/without honey is very spread in Syria (Figures 5-7), for nutritional purposes, so that we estimated its effects comparing with pure honey and placebo and antibiotics on some kinds of bacteria in-vitro, as a part of ethno-medicinal survey and efficacy evaluation of Arabic TM/CAM in Syria "according to WHO strategy" this study to be carried out by Damascus University incooperation with Syria Trust for Development and Al Jazeera Private University (JPU).

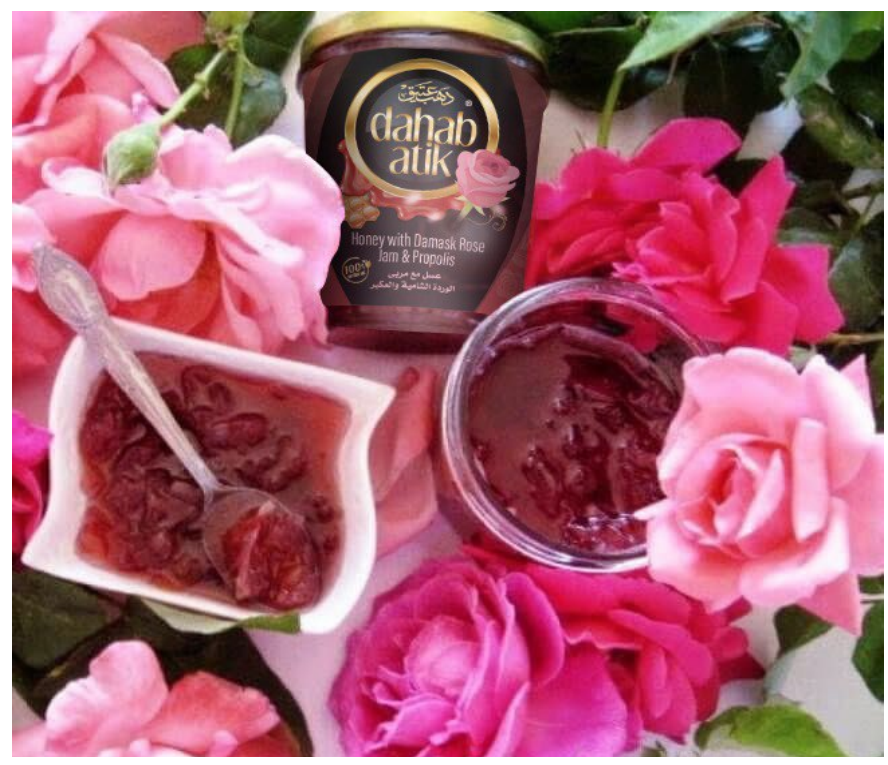

Figure 5. Damask rose traditional product.

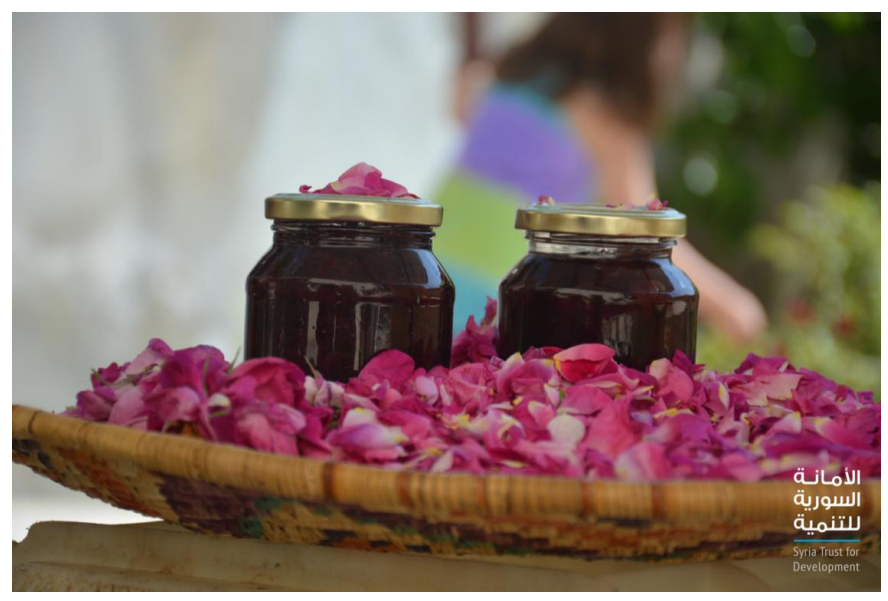

Figure 6. The traditional damask rose jam @ c courtesy of the Syria trust for development, 2016. 


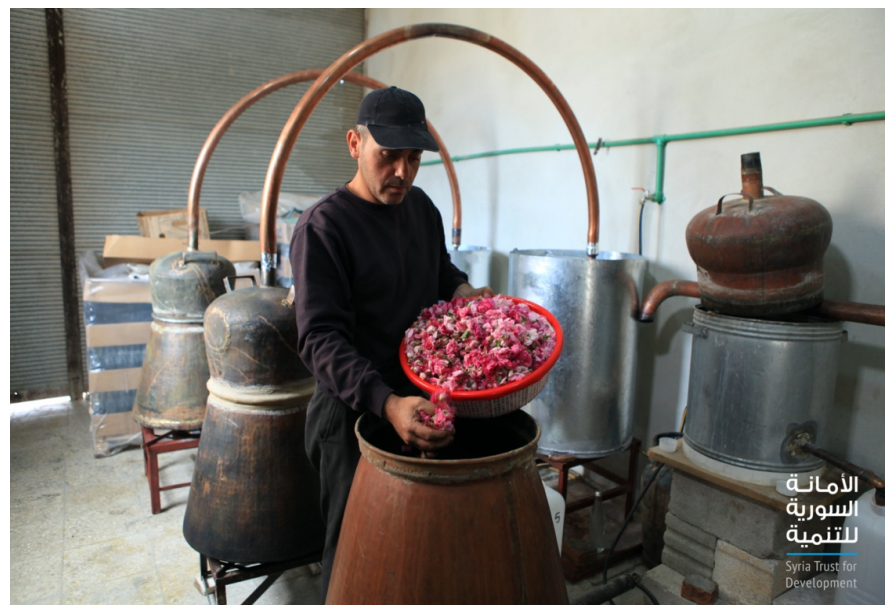

Figure 7. The distillation of the roses through copper distilleries called Alkirkh placed over a fire after adding water to the petals and waiting for the boil. Rose water is then placed in vials until it is ready for use. (c) Courtesy of the Syria trust for Development, 2016.

Because of the interest of WHO Traditional Medicines unit in traditional medicine, it focused on research on herbal medicines especially on the methodologies for research and on specific herbal remedies in their several strategies; So the WHO Traditional Medicine Strategy 2014-2023 was developed and launched in response to the World Health Assembly resolution on traditional medicine No. (WHA62.13). The strategy aims to support Member States in developing proactive policies and implementing action plans that will strengthen the role traditional medicine which plays an important role in keeping populations healthy, the updated strategy for the period 2014-2023 devotes more attention than its predecessor to prioritizing health services and systems, including traditional and complementary medicine products, practices and practitioners [33].

\section{Material and Methods}

\subsection{Experimental}

Damask rose were plucked early in the morning before sunrise during the months of spring and utilized for distillation.

\subsection{Distillation}

A direct-fired field distillation unit containing distillation tank a column, condenser and receiver all made up of stainless steel.

Oil collected in the receiver was separated from the rose water and dried over anhydrous $\mathrm{Na}_{2} \mathrm{SO}_{4}$ as mentioned by (Kiran et al. 2002) [34].

In this study, We have examined the effect of honey rose jam, which was mentioned in the old traditional recipes in the laboratory, by comparing the bioactivity of extracts (black seeds honey-Syrian traditional mixture "Damask rose jam with honey and Propolis"-Propolis water soluble 70\%, Propolis water 
soluble 90\%) against different strains of pathogenic bacteria and this bioactivity was compared with the antibacterial activities of six antibiotics.

Microorganisms were obtained from the Tishreen university Hospital, Bacterial cultures were stored on appropriate agar slants at suitable temperature during whole study and used as stock cultures. Then the cultures were tested using six different antibiotics (i.e. Ampicllin (AMP), Cefotaxime (CTX), Chloramphenicol, (CHL), Tetracycline (TE), Vancomycin (VA) and Gentamycin $(\mathrm{GN})$ ).

\section{Results}

\subsection{Identification of Pathogenic Bacteria Species}

The following of the pathogenic bacteria isolates such as (Escherichia coli, Klebsiella pneumoniae, Staphylococcus aureus, Streptococcus pneumoniae) have been used in the study and their identification was confirmed by laboratory studying for their morphological and microscopic. Biochemical tests were carried out by using API 20E analytical system for identification of pathogenic bacteria based on Bergey's manual of determinative bacteriology and other taxonomic references [35].

\subsection{Staphylococcus aureus}

The color of colonies was yellow as shown in Figure 8. Microscopic study at $400 \times$ showed that the cells of this isolate were Gram-positive and non-motile. The results showed that this bacterium was able to break down blood when cultivated on the blood agar. It is considered one of the pathogenic bacteria for its coagulation of plasma (Coagulase positive). The results of the biochemical tests also showed that it was CAT-positive.

The results of API 20E (Figure 9) showed that this bacteria was not able to ferment lactose (negative ONPG), and did not convert ornithine to putrescine (negative ODC), did not convert arginine to citrulline (ADH negative), lysine to cadaverine (negative LDC), and tryptophan to pyruvic indole (negative TDA). The results also showed the inability of these bacteria to dissolve the urine and

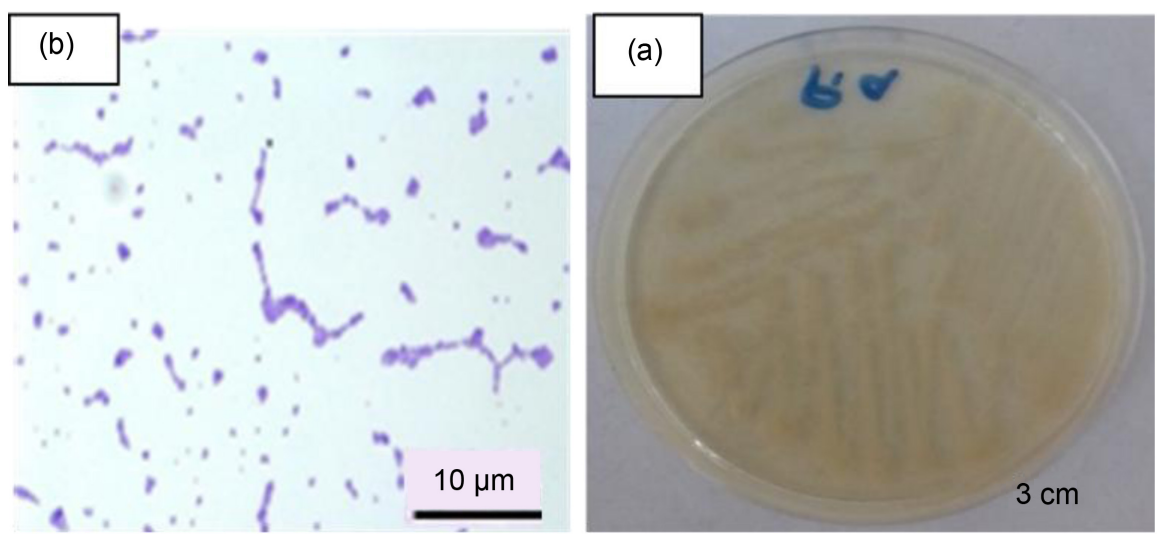

Figure 8. (a) Growth of $S$. aureus colonies. (b) The form and color of cells in Gram stain. 


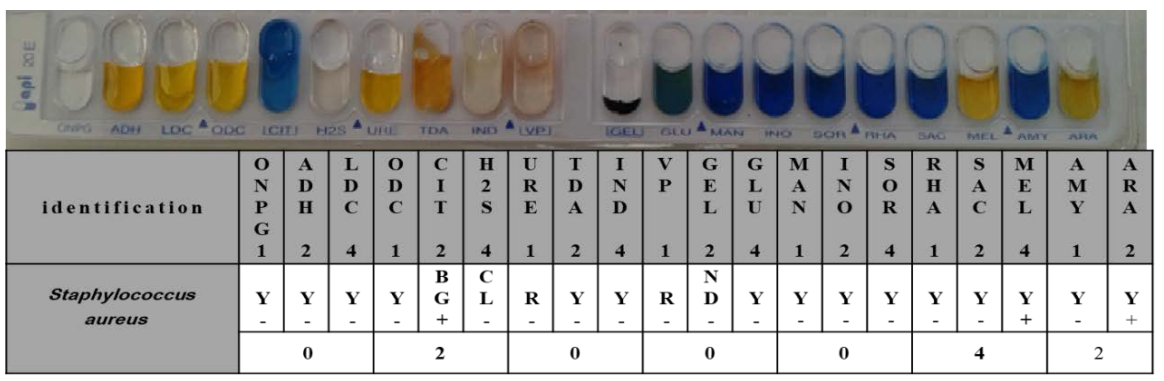

Figure 9. Results of biochemical tests using the Staphylococcus aureus API 20E analytical system.

produce indole (negative IND). It cannot form acetoin.

The results also showed the ability of these bacteria to consume citrates and produce hydrogen sulfide gas. As for sugars, it has been observed that these bacteria do not ferment glucose, mannitol, inositol, sorbitol, rhamnose, sucrose and amygdalin, but it ferments arabinose and melibiose. In addition, the results showed that it is a negative oxidase, and negative gelatinase (Figure 2). The results of the biochemical tests for Staphylococcus aureus bacteria were identical to those obtained by (Jayammal \& Sivakumar, 2013) [36].

\subsection{Streptococcus pneumoniae}

It appears that the cells of these bacteria are straight or curved bacilli, Gram-positive, aerobic, with length from 1.5 - 3 um and width $0.5-0.8 \mathrm{um}$, grouping in the form of single cells or intercessions or short chains, with large round colonies approximately $3 \mathrm{~mm}$ in diameter, with an edge Irregular, semi-transparent, colonies of rough irregular (Figure 10 and Figure 11).

The API 20E profile for Streptococcus pneumoniae showed that this isolate was not able to ferment lactose (negative ONPG), did not convert ornithine to putrescine (negative ODC), nor did convert lysine to cadaverine (negative LDC). While arginine is converted to citrulline (positive $\mathrm{ADH}$ ), tryptophan is converted to peruvic indole (positive TDA). It was also observed that this bacteria was able to consume citrates but it was negative urease (negative URE), did not produce hydrogen sulfide gas (negative $\mathrm{H} 2 \mathrm{~S}$ ), and did not produce indole (negative IND). As for sugars, it has been observed that this bacteria isolate does not ferment glucose (GLU), mannitol (MAN), inositol (INO), sorbitol (SOR), rhamnose (RAM), sucrose (SAC), melibiose (MEL) and amygdalin (AMY), while it was able to ferment arabinose (ARA), and formation of acetylene. In addition, it was negative oxidase, negative gelatinase and negative Voges-Proskauer test (Figure 11).

\subsection{Escherichia Coli}

Figure 12 and Figure 13 show the cells form in the microscope (400x) and results of biochemical tests by API 20E. The cells were short-bacilli, motile and gram-negative; their colonies have purple color with metallic sheen. On Eosin 

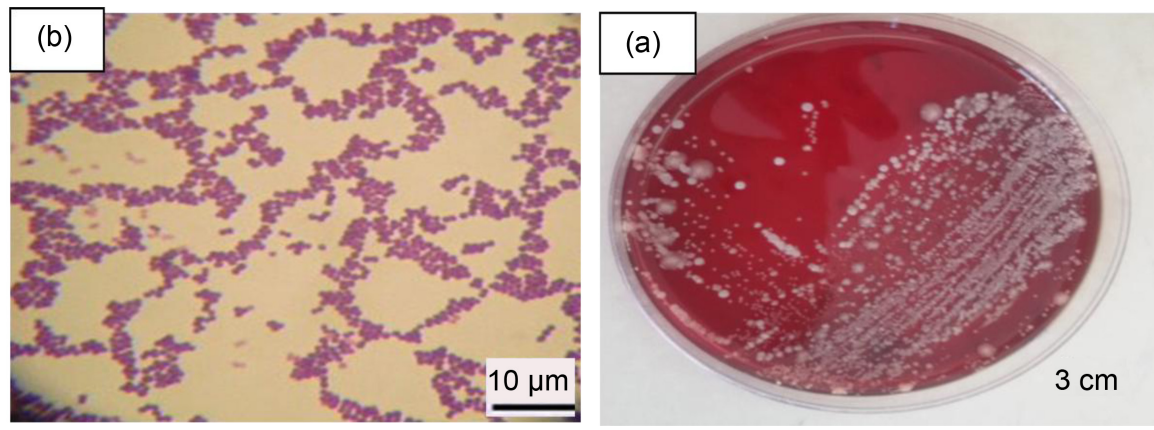

Figure 10. (a) Growth of the Streptococcus pneumoniae colonies. (b) The form of the colored cells with a Gram stain.

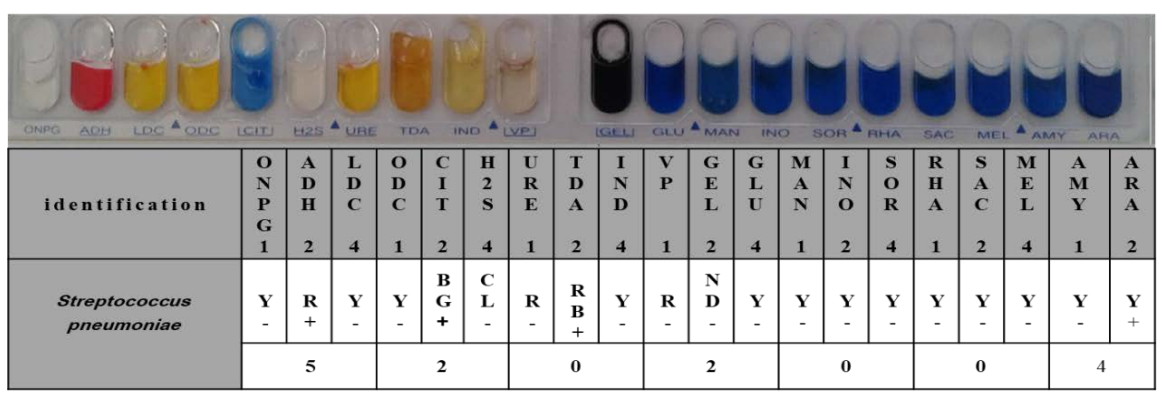

Figure 11. Results of biochemical tests using the API 20E analytical system for Streptococcus pneumoniae.
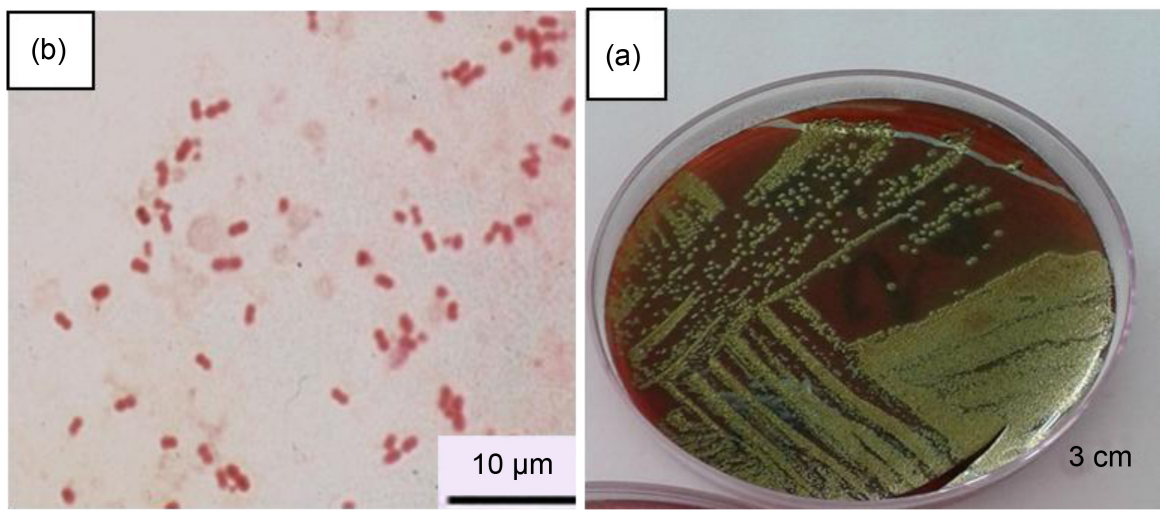

Figure 12. (a) Growth of E. coli bacteria colonies. (b) The shape of colored cells with a Gram stain.

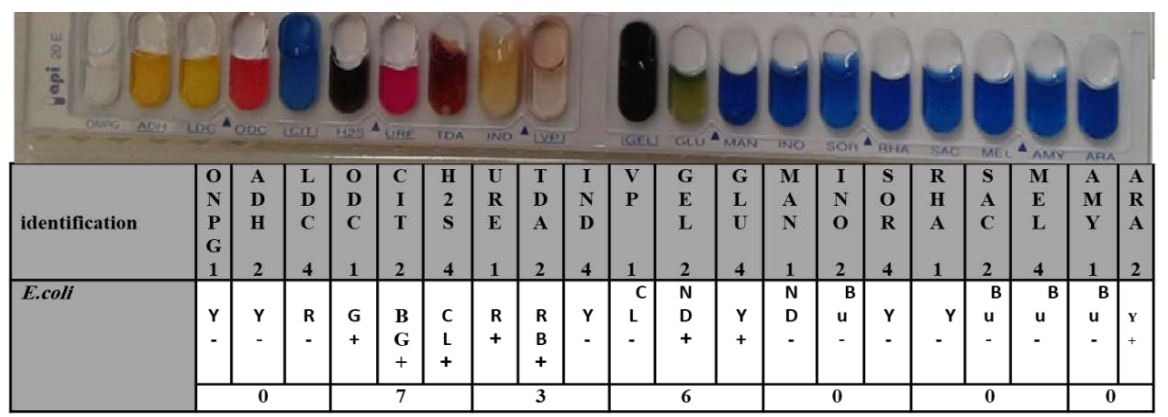

Figure 13. Results of biochemical tests using the API 20E analytical system for E. coli bacteria. 
Methylene Blue (EMB) agar. This bacteria found in the human intestine naturally without any symptoms or without causing any health problems, but it can cause several types of diseases such as cholecystitis, septicemia, urinary tract infections, neonatal meningitis and pneumonia (Dib et al., 2013) [37].

The results of biochemical tests using API 20E in Figure 14 showed that this bacteria was able to ferment lactose (negative ONPG), cannot convert arginine to citrulline (ADH negative) and lysine to cadaverine (LDC negative). It also showed unable to produce indole (negative IND) and formation acetoin (Voges-Proskauer negative test), as it has negative oxidase test. While it was possible to convert ornithine to putrescine (positive ODC), it consumed citrate and produced of hydrogen sulfide gas. It was positive gelatinase and positive urease. As well as it can convert tryptophan into a pyruvic indole. As for sugars, it has been observed to ferment glucose and arabinose while it was unable to ferment mannitol, sorbitol, rhamnose, inositol, melibiose, sucrose and amygdalin (Figure 15).

\subsection{Klebsiella pneumoniae}

The results showed that the cells of this bacteria were immobile, short bacilli and gram-negative. The cell is surrounded by capsule which gives it resistance (Figure 14).
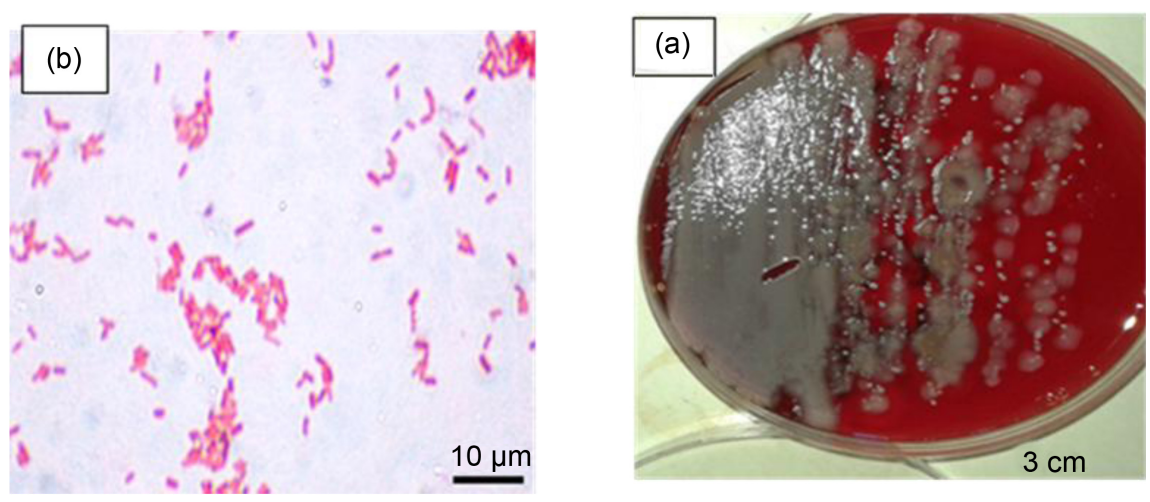

Figure 14. (a) The growth of the Klebsiella pneumoniae colonies. (b) The form of the colored cells with a gram dyes.

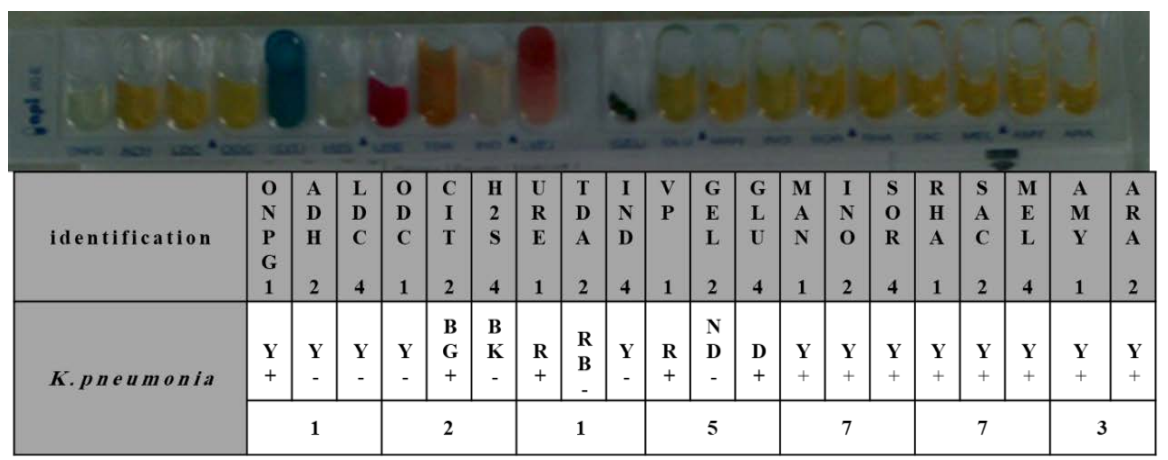

Figure 15. Results of biochemical tests using API 20E analytical system for K. pneumoniae bacteria. 
The results of API 20E for $K$. pneumoniae showed that this bacteria was able to ferment lactose (positive ONPG), consume citrates as a single carbon source and produce urease. While it was unable to convert ornithine to putrescine (negative $\mathrm{ODC}$ ), and arginine to citrulline (ADH negative) and transform lysine into cadaverine (negative LDC). It did not produce hydrogen sulfide gas, did not convert tryptophan into pyruvic indole (TDA negative) and did not produce indole (negative IND). As for the sugars, it was observed that it was able to ferment glucose, sucrose, and melibiose, amygdalin, arabinose, inositol, sorbitol, mannitol and rhamnose. It was able to form acetoin (Voges-Proskauer negative test), but it was negative oxidase and gelatinase tests. Different products of Damask rose were tested on different pathogens and their antimicrobial activities were listed in Table 1 . Their effects on the growth of these bacteria are also shown in Figure 16.

Table 1. The antibacterial activity of the organic extracts (black seeds honey-Syrian traditional mixture "Damask rose jam with honey and Propolis"-Propolis water soluble 70\%, Propolis water soluble 90\%).

\begin{tabular}{ccccc}
\hline Pathogens & $\begin{array}{c}\text { Black } \\
\text { seeds } \\
\text { honey }\end{array}$ & $\begin{array}{c}\text { Syrian traditional } \\
\text { mixture "Damask } \\
\text { rose jam with honey } \\
\text { and Propolis" }\end{array}$ & $\begin{array}{c}\text { Propolis } \\
\text { water soluble } \\
70 \%\end{array}$ & $\begin{array}{c}\text { Propolis } \\
\text { water } \\
\text { soluble } \\
90 \%\end{array}$ \\
\hline Staphylococcus aureus & 24 & 32 & 19 & 18 \\
Streptococcus pneumoniae & 22 & 27 & 17 & 16 \\
Escherichia coli & 18 & 22 & 7 & 6 \\
Klebsiella pneumoniae & 21 & 25 & 12 & 10 \\
\hline
\end{tabular}
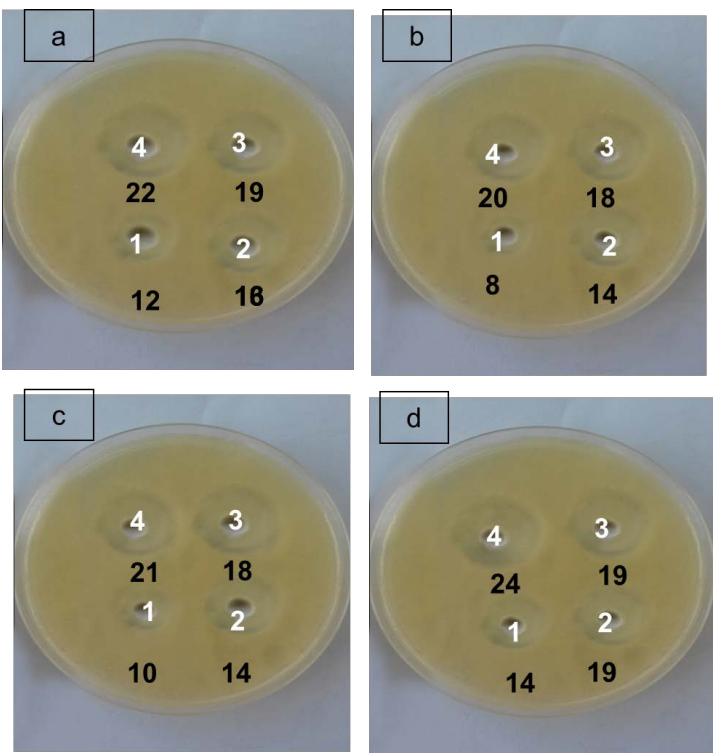

Figure 16. Antibacterial activity of organic extracts (a) Black seeds honey; (b) Syrian traditional mixture; "Damask rose jam with honey and Propolis"; (c) Propolis water soluble 90\%; (d) Propolis water soluble $70 \%$ towards pathogenic bacteria such as (4) Staph. aureus, (3) Strep. pneumoniae, (2) K. pneumoniae and (1) E. coli. 
The results presented in Table 2 and Figure 17, showed that the antibacterial activity for of both organic extracts against $\mathrm{G}^{-}$pathogenic bacteria was lower than $\mathrm{G}^{+}$pathogenic bacteria, and this can be attributed to a difference in the cellular wall structure between Gram-positive and Gram-negative bacteria. This explains the fact that it is difficult to allow the cell wall of Gram-negative bacteria to have the influence of polar and non-polar molecules.

\subsection{Pathogen Sensitivity Test for Commercial Antibiotics}

The sensitivity of pathogenic bacteria isolates toward some of antibiotics was tested using the disc diffusion method (Bauer et al., 1966) [38].

Table 2. The antibacterial activity of the organic extracts (black seeds honey-Syrian traditional mixture "Damask rose jam with honey and Propolis"-Propolis water soluble $70 \%$, Propolis water soluble $90 \%$ ) when adding Damask rose water.

\begin{tabular}{ccccc}
\hline Pathogens & $\begin{array}{c}\text { Black seeds } \\
\text { honey }\end{array}$ & $\begin{array}{c}\text { Syrian traditional } \\
\text { mixture "Damask } \\
\text { rose jam with } \\
\text { honey and Propolis" }\end{array}$ & $\begin{array}{c}\text { Propolis water } \\
\text { soluble } 70 \%\end{array}$ & $\begin{array}{c}\text { Propolis water } \\
\text { soluble } 90 \%\end{array}$ \\
\hline $\begin{array}{c}\text { Staphylococcus aureus } \\
\text { Streptococus pneumoniae }\end{array}$ & 22 & 20 & 21 & 24 \\
Escherichia coli & 19 & 18 & 18 & 14 \\
Klebsiella pneumoniae & 16 & 8 & 14 & 19 \\
\hline
\end{tabular}
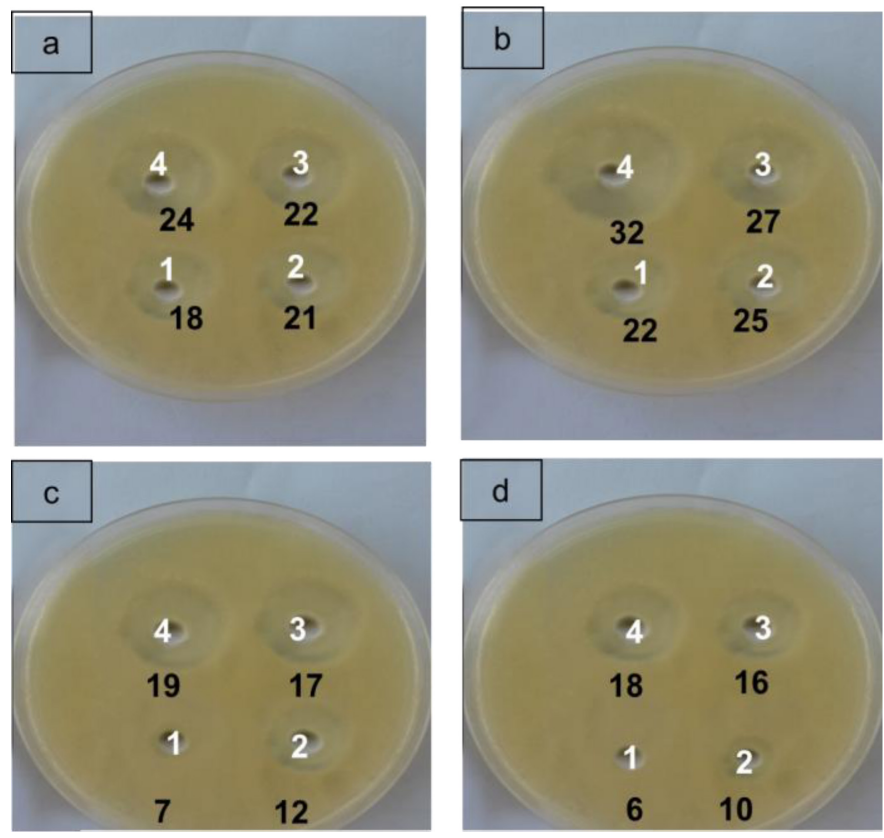

Figure 17. Antibacterial activity of organic extracts with Damask rose water (a) Black seeds honey; (b) Syrian traditional mixture; "Damask rose jam with honey and Propolis"; (c) Propolis water soluble 90\%; (d) Propolis water soluble 70\% towards pathogenic bacteria such as (4) Staph. aureus, (3) Strep. pneumoniae, (2) K. pneumoniae and (1) E. coli. 
The antibiotics used in this study belong to different groups: the penicillins such as ampicillin, the third-generation cephalosporins such as cefotaxime, and aminoglycosides such as gentamycin, in addition to chloramphenicol that belongs to chloramphenicol, while the antibiotic tetracycline from the tetracyclines group, in addition to various antibiotics, such as vancomycin. These antibiotics were adopted in this study because they are commonly and frequently used. Table 3 shows that the averagediameters of the Inhibition zones $(\mathrm{mm})$ of sensitivity to antibiotics used in the study, which is measured in the Muller-Hinton agar according to the National Committee for Clinical Laboratory Standards NCCLS (2004) [39].

\subsection{Pathogen Sensitive Bacteria for Commercial Antibiotics}

The data presented in Table 4 showed that the pathogen bacterial species varied in their sensitivity to the antibiotics used some of them showed resistance to most of tested antibiotics, such as $K$. pneumoniae, while the other pathogen bacterial species showed varying sensitivity to some antibiotics according to NCCLS standards (2004).

Table 3. The average diameters of the inhibition zones ( $\mathrm{mm}$ ) according to the NCCLS (2004) standards of sensitivity to antibiotics Muller-Hinton agar.

\begin{tabular}{cccccc}
\hline \multicolumn{3}{c}{$\begin{array}{c}\text { Theaverage diameters of the } \\
\text { inhibition zones }(\mathrm{mm})\end{array}$} & Antibiotics & \\
\hline $\begin{array}{c}\text { Sensitive } \\
(\mathrm{S}) \geq\end{array}$ & $\begin{array}{c}\text { Intermediate } \\
(\mathrm{I})\end{array}$ & $\begin{array}{c}\text { Resistant } \\
(\mathrm{R}) \leq\end{array}$ & $\begin{array}{c}\text { Disc Concentration } \\
(\mu \mathrm{g} / \text { disc })\end{array}$ & Symbol & Antibiotic \\
\hline 17 & $14-16$ & 13 & 10 & AMP & Ampicllin \\
23 & $15-22$ & 14 & 30 & CTX & Cefotaxime \\
18 & $15-17$ & 12 & 30 & CHL & Chloramphenicol \\
18 & $13-18$ & 12 & 30 & TE & Tetracycline \\
17 & $15-16$ & 14 & 30 & VA & Vancomycin \\
15 & $13-14$ & 12 & 10 & CN & Gentamycin \\
\hline
\end{tabular}

Table 4. The sensitivity of pathogenic bacterial isolates for antibiotics used.

\begin{tabular}{ccccc}
\hline Antibiotics & K. pneumoniae & E. coli & S. pneumonia & S. aureus \\
\hline Ampicllin (AMP) & 6 & 9 & 8 & 6 \\
Cefotaxime (CTX) & $\mathrm{R}$ & $\mathrm{R}$ & $\mathrm{R}$ & $\mathrm{R}$ \\
Chloramphenicol & 19 & 25 & 6 & 23 \\
(CHL) & $\mathrm{I}$ & $\mathrm{S}$ & $\mathrm{R}$ & $\mathrm{S}$ \\
Tetracycline (TE) & 14 & 19 & 6 & 6 \\
Vancomycin (VA) & $\mathrm{I}$ & $\mathrm{S}$ & $\mathrm{R}$ & $\mathrm{R}$ \\
& $\mathrm{R}$ & 6 & 27 & 22 \\
Gentamycin (GN) & 6 & $\mathrm{R}$ & $\mathrm{S}$ & $\mathrm{S}$ \\
& $\mathrm{R}$ & 9 & 6 & 12 \\
& 6 & $\mathrm{R}$ & $\mathrm{R}$ & $\mathrm{I}$ \\
\hline
\end{tabular}

$\mathrm{R}=$ Resistant. $\mathrm{I}=$ Intermediate. $\mathrm{S}=$ Sensitive. 
Staphylococcus aureus was only sensitive tocefotaxime, tetracycline and gentamycin and showed moderate sensitivity to vancomycin, whereas, it was resistant to chloramphenicol and ampicillin.

On the other hand, Streptococcus pneumoniae showed resistance to some antibiotics (such as cefotaxime, chloramphenicol, vancomycin and ampicillin) and high sensitivity to tetracycline and gentamycin.

Escherichia coli bacteria was sensitive only to cefotaxime, chloramphenicol and gentamycin, while it was resistant to tetracycline, ampicllin and vancomycin.

The Klebsiella pneumoniae showed higher resistance than other pathogenic bacterial species and showed only moderate sensitivity to cefotaxime.

Compare the bioactivity of the extracts (black seeds honey-Syrian traditional mixture "Damask rose jam with honey and Propolis"-Propolis water soluble $70 \%$, Propolis water soluble 90\%) with antibiotics against the pathogen bacteria:

It is observed from Figure 18 that the bioactivity of the mixture against this type of bacteria was very high 32 which is higher than all antibiotics such as CTX 23 and TE 22 in addition to the black seeds honey which followed the mix in terms of bioactivity 24 .

The result in Figure 19, showed that the bioactivity of mixture against this type of bacteria was very high 27 which was higher than all antibiotics such as GN 23 and TE 27 in addition to the black seed honey which followed the mix in terms of bioactivity 22 .

The mixture was also distinctive and with a high bioactivity, which converges the commercial antibiotics of this type of bacteria as shown in Figure 20.

Figure 21 showed that the bioactivity of the mixture against this type of bacteria was very high 25 which was higher than all antibiotics such as CTX 19 and

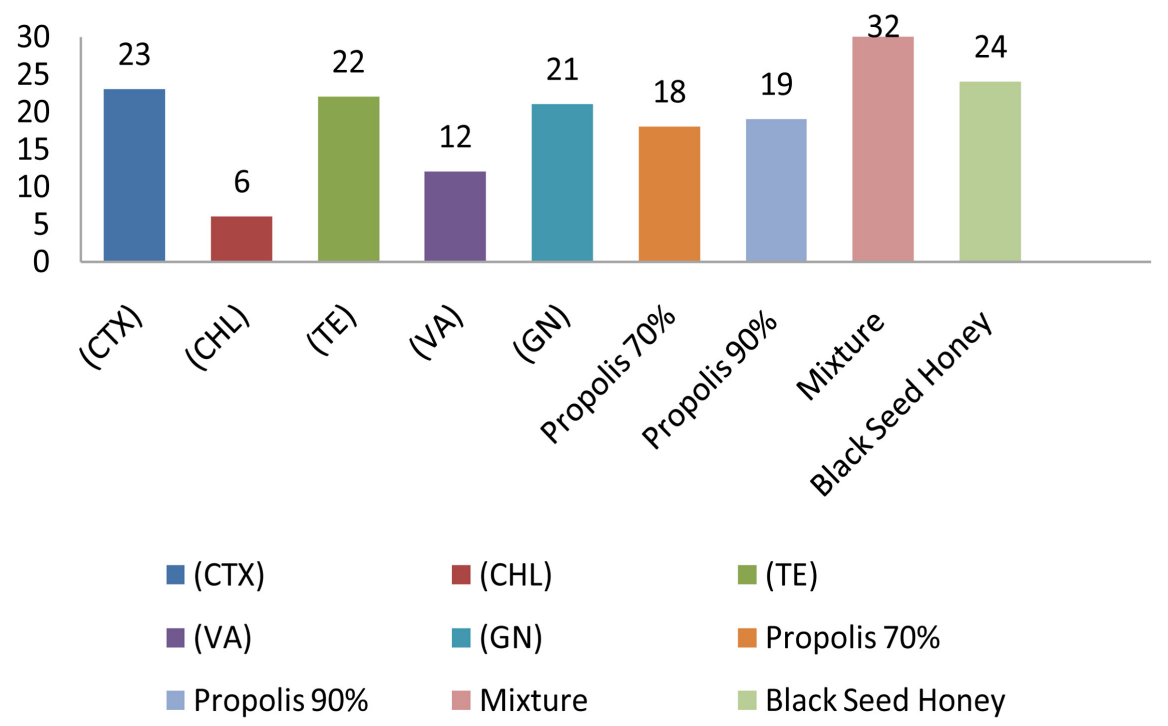

Figure 18. Comparison of bioactivity of different extracts (Black seeds honey-Syrian traditional mixture "damask rose jam with honey and Propolis"-Propolis water soluble $70 \%$, Propolis water soluble 90\%) and different antibiotics against $S$. aureus bacteria. 


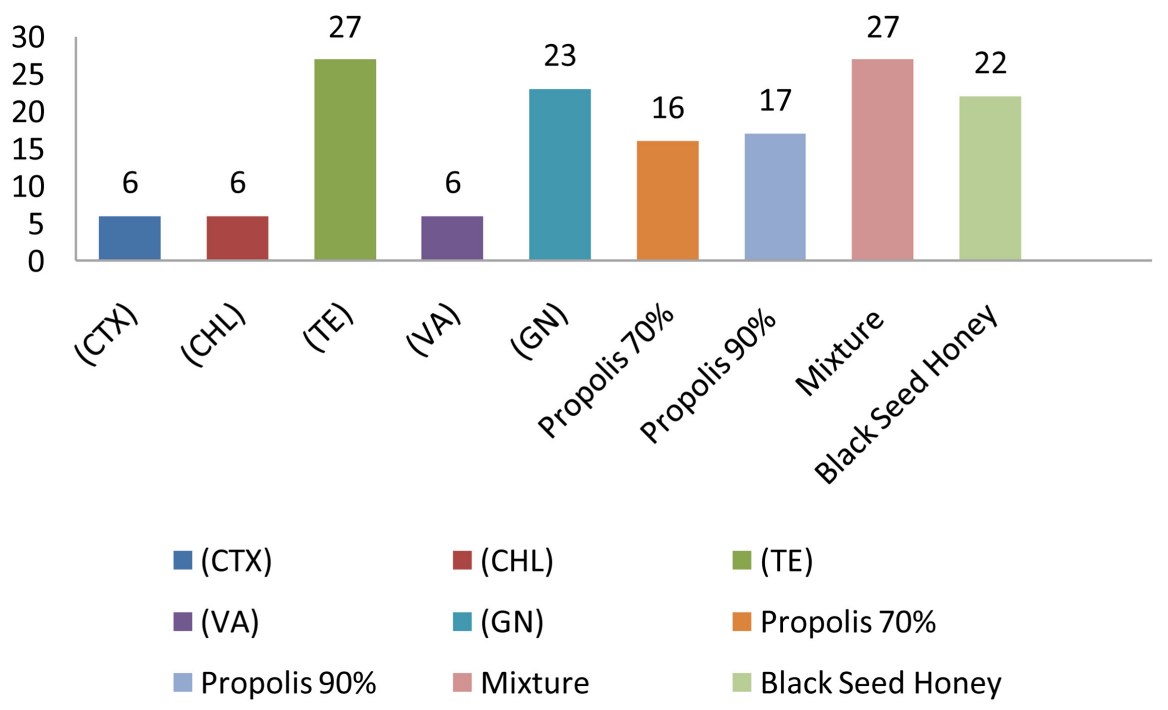

Figure 19. Comparison of bioactivity of different extracts (Black seeds honey-Syrian traditional mixture "Damask rose jam with honey and Propolis"-Propolis water soluble $70 \%$, Propolis water soluble $90 \%$ ) and different antibiotics against $S$. pneumonia.

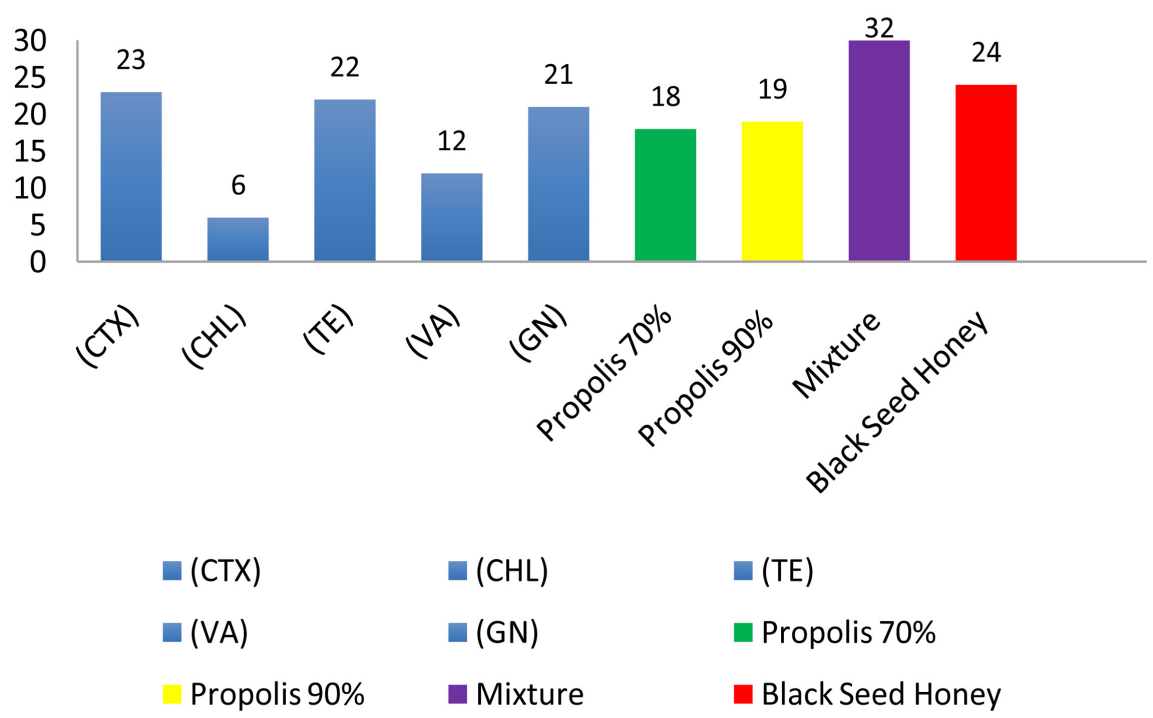

Figure 20. Comparison of bioactivity of different extracts (black seeds honey-Syrian traditional mixture "Damask rose jam with honey and Propolis"-Propolis water soluble $70 \%$, Propolis water soluble $90 \%$ ) and different antibiotics against E. coli.

WUM 14 Here we note a large difference that tends to the mixture in terms of the potency of its bioactivity for this type of bacteria in addition to the black seeds honey which followed the mix in terms of effectiveness 21 .

Comparison of the biological efficacy of the extracts (black seeds honey-Syrian traditional mixture "Damask rose jam with honey and Propolis"-Propolis water soluble 70\%, Propolis water soluble 90\%) when addition Damask rose essential oil to each of them with antibiotics to the pathogen bacteria.

Figure 22 showed that the bioactivity of the mixture against this type of bacteria was very high 27 which were higher than all antibiotics such as CTX 23 and 


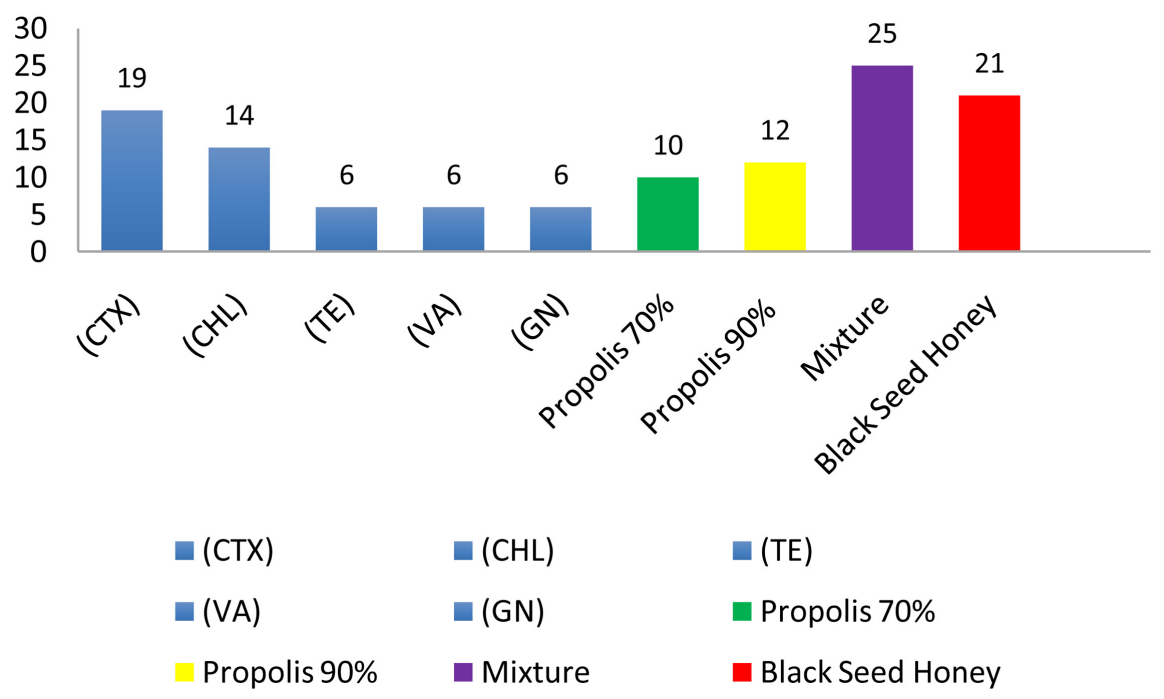

Figure 21. Comparison of bioactivity of different extracts (black seeds honey-Syrian traditional mixture "Damask rose jam with honey and Propolis"-Propolis water soluble $70 \%$, Propolis water soluble $90 \%$ ) and different antibiotics against $K$. pneumoniae.

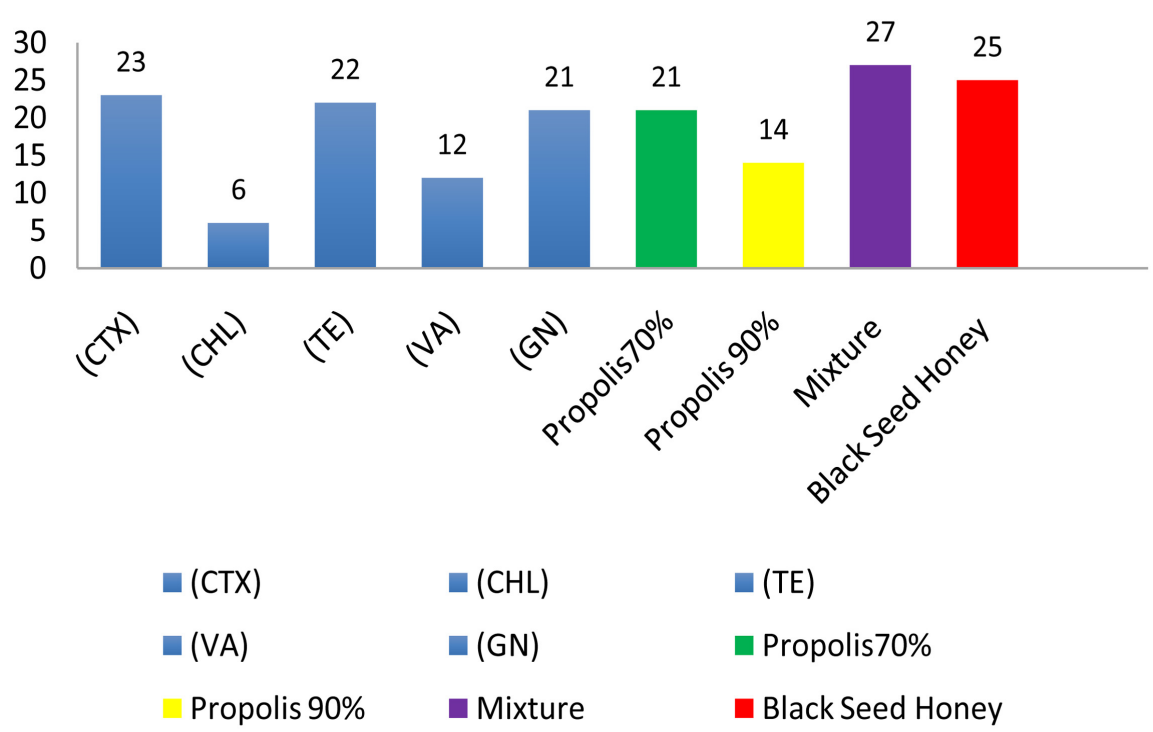

Figure 22. Comparison of bioactivity of different extracts with damask rose essential oil (black seeds honey-Syrian traditional mixture "Damask rose jam with honey and Propolis"-Propolis water soluble 70\%, Propolis water soluble 90\%) and different antibiotics against $S$. aureus bacteria.

TE 22 in addition to the black seeds honey, which followed the mixture in terms of effectiveness 25 .

\section{Conclusions}

There is a current trend of discovery and applications of bioactive agents from natural sources [40]. The results showed that the traditional Syrian traditional mixture of Damask rose jam with honey and Propolis was effective for most of the studied pathogens. These bacteria cause many diseases such as infections of 
the digestive system, chest and urinary tract.

It was followed by black seeds honey, which was effective against bacteria, followed by the second generation antibiotics.

Thus, the Syrian traditional mixture of Damask rose jam with honey and Propolis can be considered as a functional food (healthy food) which is rich in vitamins such as vitamin $\mathrm{C}$ and some vitamins $\mathrm{B}$ and $\mathrm{D}$, iron, calcium and other minerals. In addition, it is rich in antioxidants, and this confirms what was stated in ancient Arabic manuscripts about the importance of this Syrian traditional mixture in treatment many diseases.

\section{Acknowledgements}

The authors would like to express their gratitude to Mr. Fares Kallas the general secretary of the Syria Trust for Development for his kind support and to the laboratory technicians who helped in extractions, culture preparation and all lab works at Al Jazeera Private University, Damascus University, Faculty of Pharmacy (Dr. Jameela Hasian, Dr. Rasha El-Khateeb), Al Baath University, Faculty of Pharmacy (Dr. Haifa Al-Ali) and Tishreen University, Higher Institute of Marine Research (Dr. Samer Ghadeer, Dr. Badr Al-Ali). Their thanks are also extended to The Syria Trust for Development (Mr. Shadi Alelshi, Mrs. Reme Sakr, Mrs. Reem Alibraheem, Mrs. Areen Al-Ali, Mr. Houssam Akel) and the Syrian Scientific Society for Herbal Medicines and Complementary Medicines and Nutrition (Chemist. Hisham Kasem, Mr. Ibrahim Hawary) for making this work possible.

\section{Conflicts of Interest}

The authors declare no conflicts of interest regarding the publication of this paper.

\section{References}

[1] (2017) Sakr Reme, Syria Trust for Development, Chapter 7. Traditional Medicine in Syria: Knowledge, Beliefs \& Experiences. Traditional Medicine Sharing Experiences from the Field, ICHCAP and \#HeritageAlive and ichngoforum, Living Heritage Series UNESCO.

[2] Roche, J., Trivedi, R., Drani, E., Bhattacharya, A., vd Zeijden, A., Serin, S.T., Zingari, V., Jayaran, Dr.V., Romankova, E., Deacon, H., Ogieriakhi, J., Houët, F., Leonce, K., Desiderio, G., Cachat, S., Bute, S., Otto, R.B.D., Quinto, O., Caicedo, J.G. and Falk, E. (Editor in Chief) (2017) Traditional Medicine Sharing Experiences from the Field, ICHCAP and \#HeritageAlive and ichngoforum, Living Heritage Series UNESCO.

[3] https://ich.unesco.org/en/RL/-01369

[4] Widrlechner, M.P. (1981) History and Utilization of Rosa damascene. Economic Botany, 35, 42-58. https://doi.org/10.1007/BF02859214

[5] Mahboubi, M. (2016) Rosa damascena as Holy Ancient Herb with Novel Applications. Journal of Traditional and Complementary Medicine, 6, 10-16. https://doi.org/10.1016/j.jtcme.2015.09.005 
[6] Kaul, V.K., Singh, V. and Singh, B. (2000) Damask Rose and Marigold: Prospective Industrial Crops. Journal of Medicinal and Aromatic Plants, 22, 313-318. [Google Scholar]

[7] Krussman, G. (1981) The Complete Book of Roses. Timber Press, Portland, Oregon. [Google Scholar]

[8] Nikbakht, A. and Kafi, M. (2008) A Study on the Relationships between Iranian People and Damask Rose (Rosa damascena) and Its Therapeutic and Healing Properties. Acta Horticulturae (ISHS), 790, 251-254. [Google Scholar] https://doi.org/10.17660/ActaHortic.2008.790.36

[9] Yassa, N., Masoomi, F. and Hadjiakhoondi, A. (2009) Correspondence Chemical Composition and Antioxidant Activity of the Extract and Essential Oil of Rosa damascena from Iran, Population of Guilan. Daru, 17, 175-180. [Google Scholar]

[10] Vetricka, V. (1997) Roses. R\&B Press, London, England. [Google Scholar]

[11] Tabaei-Aghdaei, S.R., Babaei, A., Khosh-Khui, M., Jaimand, K., Rezaee, M.B., Assareh, M.H. and Naghavi, M.R. (2007) Morphological and Oil Content Variations Amongst Damask Rose (Rosa damascena Mill.) Landraces from Different Regions of Iran. Scientia Horticulturae, 113, 44-48. https://doi.org/10.1016/j.scienta.2007.01.010

[12] Zargari, A. (1992) Medicinal Plants. 5th Edition, Tehran University Press, Tehran. [Google Scholar]

[13] https://https://en.wikipedia.org/wiki/Rosa_\%C3\%97_damascena

[14] Putnam, G.P. and Perkins, F.B. (1877) The World's Progress. A Dictionary of Dates: Being a Chronological and Alphabetical Record of All Essential Facts in the Progress of Society, from the Creation of the World to the Present Time with a Chart. 387 p.

[15] Dalfardi, B., Heydari, M., Golzari, S.E., Nezhad, G.S.M. and Hashempur, M.H. (2014) Al-Baghdadi's Description of Venous Blood Circulation. International Journal of Cardiology, 174, 209-210. https://doi.org/10.1016/j.ijcard.2014.03.199

[16] Nayebia, N., Khalilib, N., Kamalinejadc, M. and Emtiazy, M. (2017) A Systematic Review of the Efficacy and Safety of Rosa damascena Mill. with an Overview on Its Phytopharmacological Properties. Complementary Therapies in Medicine, 34, 129-140. https://doi.org/10.1016/j.ctim.2017.08.014

[17] Avicenna (Ibn-e-sina) (2005) Al-Qanoon Fi Al-Tibb. 1st Edition, Alaalami Beirut library Press, Beirut, Lebanon, $567 \mathrm{p}$.

[18] Ali, A. and Chadi, K. (2016) The New Information's About Aromatherapy and Scents Edited by Albucasis. Journal of the International Society for the History of Islamic Medicine (JISHIM), 14-15, 64-84.

[19] Maurizio, I. (2003) Article "Western Science Could Learn a Thing or Two from the Way Science Is Done in other Cultures: Science and Culture" Viewpoint. European Molecular Biology Organization (EMBO) Reports, 4, 223.

[20] Hamarneh, S.K. (1965) The First Known Independent Treatise on Cosmetology in Spain. Bulletin of the History of Medicine, 39, 309-325.

[21] Hongratanaworakit, T. (2009) Relaxing Effect of Rose Oil on Humans. Natural Product Communications, 4, 291-296. https://doi.org/10.1177/1934578X0900400226

[22] Boskabady, M.H., Shafei, M.N., Saberi, Z. and Amini, S. (2011) Pharmacological Effects of Rosa Damascena. Iranian Journal of Basic Medical Sciences, 14, 295-307.

[23] Libster, M. (2002) Delmar's Integrative Herb Guide for Nurses. Delmar Thamson 
Learning, Albany, 360-370. [Google Scholar]

[24] Medical Economics Company (2008) PDR for Herbal Medicines (Physicians' Desk Reference for Herbal Medicines). ISBN: 1-56363-361-2, 644 p.

[25] Ding, Q. (2019) Plants \& Nations: Syria. https://news.cgtn.com/news

[26] Chadi, K., Naser, K.A. and Ali, R. (2014) Cosmetics in Arabic Medical Heritage as Example: Razes, Avicenna, Albucasis, Institute for the History of Arabic Science. University of Aleppo, Aleppo, 77 p.

[27] Widrlechner, M.P. (1981) History and Utilization of Rosa damascene. Economic Botany, 35, 42-58. [Google Scholar] https://doi.org/10.1007/BF02859214

[28] Baydar, H. and Baydar, N.G. (2005) The Effects of Harvest Date, Fermentation Duration and Tween 20 Treatment on Essential Oil Content and Composition of Industrial Oil Rose (Rosa damascena Mill.). Industrial Crops and Products, 21, 251-255. [Google Scholar] https://doi.org/10.1016/j.indcrop.2004.04.004

[29] Albucasis The Manuscript 'al-Tașrif liman 'ajiza 'an al-ta'ālîf' (Arabic Text). The Nineteenth Treatise on Cosmetics, Second Part, Hasan Husni ms. No. 900of Ayyub, Egypt, Second Volume.

[30] https://en.wikipedia.org/wiki/Jallab

[31] https://honestcooking.com/jallab-a-refreshingly-sweet-summer-drink/

[32] Pal, P.K. (2013) Evaluation, Genetic Diversity, Recent Development of Distillation Method, Challenges and Opportunities of Rosa damascena: A Review. Journal of Essential Oil Bearing Plants, 16, 1-10. https://doi.org/10.1080/0972060X.2013.764176

[33] https://www.who.int/medicines/publications/traditional/trm_strategy14_23/en/

[34] Kiran, G.D., Babu, B.S., Joshi, V.P. and Singh, V. (2002) Essential Oil Composition of Damask Rose (Rosa damascena Mill.) Distilled under Different Pressures and Temperatures. Flavour and Fragrance Journal, 17, 136-140. https://doi.org/10.1002/ffj.1052

[35] Buchanan, R.E. and Gibbons, N.E. (1974) Bergey's Manual of Determinative Bacteriology. 8th Edition, William \& Wilkins, Baltimore, USA, 1-573.

[36] Jayammal, D. and Sivakumar, T. (2013) Antibacterial Activity of Protein Extract of Marine Pseudomonas aeruginosa against Bacterial Pathogens. International Journal of Current Microbiology and Applied Sciences, 2, 207-216.

[37] Dib, J., Liebl, W., Wagenknecht, M., Farias, M. and Meinhardt, F. (2013) Extrachromosomal Genetic Elements in Micrococcus. Applied Microbiology and Biotechnology, 97, 63-75. https://doi.org/10.1007/s00253-012-4539-5

[38] Bauer, A.W., Kirby, W.M., Sherris, J.C. and Turck, M. (1966) Antibiotic Susceptibility Testing by a Standardized Single Disk Method. American Journal of Clinical Pathology, 45, 493-496. https://doi.org/10.1007/s00253-012-4539-5

[39] NCCLS (2004) Performance Standards for Antimicrobial Susceptibility Testing. Fourteenth Informational Supplement, Vol. 24, No. 1.

[40] Grabley, S. and Thiericke, R. (1999) Bioactive Agents from Natural Sources: Trends in Discovery and Application. In: Bhatia, P.K., Danielsson, B., Gemeiner, P., et al., Eds., Thermal Biosensors, Bioactivity, Bioaffinitty, Springer, Berlin, Heidelberg, 101-154. https://doi.org/10.1007/3-540-49811-7_4 